\title{
Genome constitution and differentiation of subgenomes in Siberian and Far Eastern endemic species of the genus Elymus (Poaceae) according to the sequencing of the nuclear gene waxy
}

\author{
A.V. Agafonov ${ }^{1} \otimes$, S.V. Asbaganov ${ }^{1}$, E.V. Shabanova (Kobozeva) ${ }^{1}$, I.V. Morozov ${ }^{2,}{ }^{3}$, A.A. Bondar $^{2}$ \\ ${ }^{1}$ Central Siberian Botanical Garden, SB RAS, Novosibirsk, Russia \\ 2 Institute of Chemical Biology and Fundamental Medicine, SB RAS, Novosibirsk, Russia \\ ${ }^{3}$ Novosibirsk State University, Novosibirsk, Russia \\ 网-mail:agalex@mail.ru
}

\begin{abstract}
Fifty-three species of perennial grasses in the genus Elymus L. (Poaceae), which are widespread in Russia, are generally assumed to have three haplome combinations: StH, StY and StHY. The StH-genome species, endemic to Russia, remain the least studied. R. Mason-Gamer and co-authors have previously shown in a series of studies that a molecular phylogenetic analysis of the low-copy gene waxy (GBSS1) sequences significantly complements cytogenetic data on the genomic constitution and evolutionary relationships among both North American and Asian species of the genus Elymus. To determine the species' genomic constitution and to evaluate the level of phylogenetic differentiation, we examined the GBSS1 gene in 18 species of Elymus from Siberia and the Russian Far East, including the following 14 endemics:E.charkeviczii, E.jacutensis, E. kamczadalorum, E. komarovii, E. kronokensis, E. lenensis, E. macrourus, E. margaritae, E. subfibrosus, E. sajanensis, E. transbaicalensis, E. peschkovae, E. uralensis, and E. viridiglumis. PCR amplification products of GBSS1 gene fragments (including exons 9-14) were cloned and 6-8 clones per accession were sequenced. It appears that all the species studied have St and $\mathrm{H}$ subgenomic gene variations. The most significant differences between the subgenomic variants $\mathrm{St}$ and $\mathrm{H}$ were found in intron 13 . The $\mathrm{H}$ subgenome contains a 21-bp-long deletion in intron 13 in all Elymus genotypes, probably derived from a common ancestor of the $\mathrm{H}$ and P genomes. Instead of this deletion, all St subgenomes have a relatively conservative sequence similar to that of the genus Pseudoroegneria, whose ancestor is considered to be the donor of the modern St subgenome for all Elymus species. Cluster phylogenetic analysis revealed differentiation in $\mathrm{St}$ and $\mathrm{H}$ subgenome sequences into two evolu-

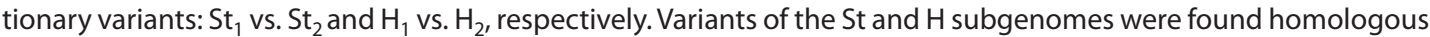
to various modern species of the ancestral genera Pseudoroegneria and Hordeum: $\mathrm{St}_{1}$ to $P$. strigosa, $\mathrm{St}_{2}$ to P. spicata,

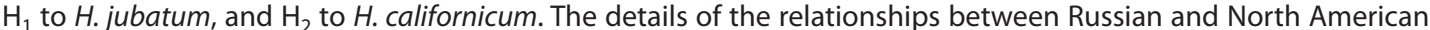
species of the genus, as well as a number of microevolutionary interconnections in the group of boreal endemic species of Siberia and the Russian Far East were revealed. The new results obtained here are essential for the development of a phylogenetically oriented taxonomic system for the genus Elymus. Key words: Elymus; phylogeny; allopolyploids; genome constitution; GBSS1.
\end{abstract}

For citation: Agafonov A.V., Asbaganov S.V., Shabanova (Kobozeva) E.V., Morozov I.V., Bondar A.A. Genome constitution and differentiation of subgenomes in Siberian and Far Eastern endemic species of the genus Elymus (Poaceae) according to the sequencing of the nuclear gene waxy. Vavilovskii Zhurnal Genetiki i Selektsii=Vavilov Journal of Genetics and Breeding. 2019;23(7):817-826. DOI 10.18699/VJ19.555

\section{Геномная конституция и дифференциация субгеномов эндемичных сибирских и дальневосточных видов рода Elymus (Роасеае) по данным секвенирования ядерного гена waxy}

\author{
А.В. Агафонов ${ }^{1}$ 囚, С.В. Асбаганов ${ }^{1}$, Е.В. Шабанова (Кобозева) $)^{1}$, И.В. Морозов ${ }^{2}$,, А.А. Бондарь ${ }^{2}$ \\ ${ }^{1}$ Центральный сибирский ботанический сад Сибирского отделения Российской академии наук, Новосибирск, Россия \\ 2 Институт химической биологии и фундаментальной медицины Сибирского отделения Российской академии наук, Новосибирск, Россия \\ ${ }^{3}$ Новосибирский национальный исследовательский государственный университет, Новосибирск, Россия \\ 凶e-mail: agalex@mail.ru
}

В России распространены 53 вида многолетних трав рода Elymus L. (Роaceae) предположительно трех гапломных комбинаций: StH, StY и StHY. Наименее изученными остаются бореальные StH-геномные виды - эндемики РФ. Ранеe R. Mason-Gamer с соавторами в серии исследований было показано, что молекулярнофилогенетический анализ последовательностей низкокопийного гена waxy (GBSS1) существенно дополняет цитогенетические данные по геномной конституции и эволюционным взаимоотношениям как среди североамериканских, так и среди азиатских видов рода Elymus. Мы исследовали ген GBSS1 у 18 видов Elymus 
из Сибири и Дальнего Востока России (включая 14 эндемичных), чтобы определить их геномную конституцию и оценить уровни филогенетической дифференциации: E. charkeviczii, E. jacutensis, E. kamczadalorum, E. komarovii, E. kronokensis, E. lenensis, E. macrourus, E. margaritae, E. subfibrosus, E. sajanensis, E. transbaicalensis, E. peschkovae, E. uralensis, E. viridiglumis. Продукты ПцР-амплификации фрагментов гена GBSS1 (область экзонов 9-14) были клонированы и секвенированы (по 6-8 клонов на образец). Все изученные виды включали субгеномные вариации St и Н. Наиболее существенные различия между субгеномными фрагментами St и H обнаружены в интроне 13. Этот интрон в субгеноме Н содержит делецию в 21 п. н. во всех генотипах Elymus, вероятно, унаследованную от общего предка геномов Н и Р. Вместо этой делеции все субгеномы St имеют относительно консервативную последовательность, близкую по нуклеотидному составу к таковой у рода Pseudoroegneria, предок которого является донором современного субгенома St всех видов Elymus. Кластерный филогенетический анализ выявил дифференциацию последовательностей каждого из субгеномов St и Н на два эволюционных варианта - условно St и St $_{2}, \mathrm{H}_{1}$ и $\mathrm{H}_{2}$. Установлено, что варианты субгеномов St и H гомогенны с различными современными видами предковых родов Pseudoroegneria и Hordeum: $\mathrm{St}_{1}-$ P. strigosa, $\mathrm{St}_{2}-$ P. spicata, $\mathrm{H}_{1}-$ H. jubatum, $\mathrm{H}_{2}-$ H. californicum. Выявлены особенности взаимоотношений между российскими и североамериканскими видами рода, а также ряд микроэволюционных связей в группе эндемичных бореальных видов Сибири и Дальнего Востока. Полученные новые данные необходимы для построения филогенетически ориентированной таксономической системы рода Elymus. Ключевые слова: Elymus; филогения; аллополиплоиды; геномная конституция; GBSS1.

\section{Introduction}

The genus Elymus L. (wildrye) is the largest genus of the tribe Triticeae Dumort in the family Poaceae Barn. It contains exclusively amphiploid self-pollinating perennial grasses (Dewey, 1984; Löve, 1984). Species of the genus are widespread on all continents from the Holarctic to the subtropics, with more than half populations growing in Central Asia (Lu, 1994). The genomic constitution of all species formed by haplomes from the ancestors of several modern genera: Pseudoroegneria (Nevski) Á. Löve (St haplome), Hordeum L. (H haplome), Agropyron Gaertn. (P haplome) and Australopyrum (Tzvelev) Á. Löve (W haplome), as well as the $\mathrm{Y}$ haplome from an unknown ancestor. The St haplome is common for all species of the genus. After institution and recognition of the genomic classification system for the tribe Triticeae (Dewey, 1984), a taxonomic system began to spread, in which the genus Elymus in the broadest sense is divided into several separate genera on the basis of the genomic composition of the species (Baum et al., 2011): Elymus L. (StStHH genome), Roegneria C. Koch (StStYY genome), Campeiostachys Drobov (StStHHYY genome), and Kengylia C. Yen \& J.L. Yang (StStYYPP genome), Douglasdeweya C. Yen, J.L. Yang et B.R. Baum (StStPP genome). According to the current concepts, the genus Elymus within Russia is divided into four sections: Turczaninovia (Nevski) Tzvelev (includes 4 species), Goulardia (Husn.) Tzvelev (includes 42 species), Elymus (includes 6 species), and Clinelymopsis (Nevski) Tzvelev (includes 1 species) (Tsvelev, Probatova, 2010). This system was built according to the traditional criteria (comparative-morphological and ecological-geographical) and ensures the integrity and consistency of the genus, but the same sections include species with different genomic constitutions.

Nowadays it becomes evident that a balanced integrated approach is required to construct a phylogenetically oriented system of taxa of the genus Elymus. The main difficulty here is in combining two entirely different methodologies in botany: traditional taxonomy with the priority of morphological criteria and molecular genomics based on the modern molecular technologies. Significant results on the use of molecular markers were obtained by R. Mason-Gamer with collaborators (Helfgott, Mason-Gamer, 2004; Mason-Gamer, 2001, 2004, 2008, 2013; Mason-Gamer et al., 1998; 2010a, b). In particular, their studies have shown that comparative data on nucleotide sequences of the low-copy gene waxy (granule-bound starch synthase 1, GBSS1) are consistent with cytogenetic data in regard to the genomic constitution and evolutionary origin of North American (Mason-Gamer, 2001) and Asian (Mason-Gamer et al., 2010a) species of the genus Elymus.

We have analyzed the applicability of the nuclear low-copy genes bmy2 and waxy, as well as ITS rRNA clusters as genetic markers for the assessment of phylogenetic relationships between species of the genus growing in Siberia and in the Russian Far East (Shmakov et al., 2015). We confirmed that comparative analysis of selected locus sequences in combination with other molecular markers allow phylogenetic relationships between taxa to be reconstructed. Moreover, our studies proved that data on the genomic constitution of species and their microevolutionary relationships are to be taken as a fundamental basis to construct phylogenetically-oriented genus systematics for the species grown in Russia. The availability of numerous GBSS1 gene sequences in the NCBI Nucleotide database (http://www.ncbi.nlm.nih.gov/nuccore) enables a more detailed assessment of the relationships between a large number of genotypes of each species in comparative studies.

Here we present a comparative analysis of nucleotides sequences of an 1300-bp-long fragment of the GBSS1 gene including exons 9 to 14 in 18 Elymus species (including 14 endemics) growing in Siberia and in the Russian Far East in order to establish or confirm their genomic constitution and to assess the evolutionary differentiation levels of subgenomes in different species. This information is essential for the construction of a phylogenetically oriented taxonomic system of the genus species growing in Russia.

\section{Materials and methods}

The analyzed accessions included genus Elymus species widespread in the Asian part of Russia, mainly with unknown or unconfirmed genomic constitutions (Supplementary 
Material 1) ${ }^{1}$. Known GBSS1 gene sequences of the St, $\mathrm{H}$ and $\mathrm{Y}$ genomes deposited in the NCBI database were used as references for comparative analysis (Supplementary Material 2). Genomic DNA was extracted from fresh or dried leaves as previously described by Khanuja et al. (1999) with modifications, or by using Nucleospin Plant II kits (Macherey-Nagel, Germany) according to the manufacturer's recommendations.

The previously described (Mason-Gamer et al., 1998) primers F-for (TGCGAGCTCGACAACATCATGCG) and M-bac (GGCGAGCGGCGCGATCCCTCGC) were used for PCR-amplification of an 1300-bp-long GBSS1 fragment overlapping gene exons from 9 to 14 . The PCR reaction mixture of a total volume of $15 \mu \mathrm{l}$ contained Taq buffer, $0.2 \mathrm{mM}$ of each dNTP, $1.5 \mathrm{mM} \mathrm{MgCl}_{2}, 1 \mu \mathrm{M}$ of each primer, 20 ng genomic DNA, and 1.0 unit of HS Taq DNA polymerase (Eurogen, RF). The following temperature profile was used (a C-1000 thermal cycler, Bio-Rad, USA): primary denaturation for $4 \mathrm{~min}$ at $94{ }^{\circ} \mathrm{C}$, then 38 three-step cycles with denaturation for $25 \mathrm{sec}$ at $94^{\circ} \mathrm{C}$, annealing for $30 \mathrm{sec}$ at $65^{\circ} \mathrm{C}$ and elongation for $1 \mathrm{~min}$ at $72^{\circ} \mathrm{C}$, followed by final elongation for $20 \mathrm{~min}$ at $72^{\circ} \mathrm{C}$ to enhance the terminal non-matrix addition of deoxyadenosine at the 3 '-end of the PCR product (MasonGamer et al., 1998). Amplification products were analyzed by $1.7 \%$ agarose gel electrophoresis in TAE buffer at an electric field strength of $4 \mathrm{~V} / \mathrm{cm}$.

Since allopolyploid Elymus genomes contain at least two subgenomic variations of the GBSS1 gene, amplification was performed in three replicates to minimize the "PCR drift" effect due to stochastic fluctuations at the initial stages of PCR (Wagner et al., 1994). The combined PCR product was ligated into vector pAL2-T (Eurogen, RF) and then cloned in chemically competent XL1-Blue E. coli cells. Positive colonies containing recombinant plasmids with a GBSS1 insert were selected by blue/white coloring of E. coli grown on Amp (+) LB-Agar containing X-gal/IPTG. Twenty white colonies for each accession were tested for an insert of the expected length by PCR-amplification with universal M13 primers (Eurogen, RF) followed by electrophoresis analysis. At least 6 colonies containing pALT2 with an insert of the expected size ( $1300 \mathrm{bp}$ ) per each accession have been grown in $4 \mathrm{ml} \mathrm{LB}$ liquid medium for 16 hours at $37^{\circ} \mathrm{C}$ and $220 \mathrm{rpm}$. Plasmid DNA was isolated with a Plasmid Miniprep Kit (Eurogen, RF) according to the manufacturer's instructions.

The Sanger sequencing reaction in a total volume of $40 \mu \mathrm{l}$ contained $0.7 \mu \mathrm{g}$ of plasmid DNA with a total length of $\sim 4300 \mathrm{bp}, 20 \mathrm{pmol}$ of primer M13F or M13R, $1.8 \mu \mathrm{l}$ of reagent BigDye v. 3.1 (ABI, USA), $7.2 \mu \mathrm{l}$ of $5 \mathrm{X}$ sequencing buffer (ABI, USA) and water up to the final volume. The temperature profile for the Sanger reaction included primary denaturation for $2 \mathrm{~min}$ at $95^{\circ} \mathrm{C}$, then 50 three-step cycles with denaturation for $30 \mathrm{sec}$ at $95^{\circ} \mathrm{C}$, then annealing for $10 \mathrm{sec}$ at $55^{\circ} \mathrm{C}$ and elongation for $4 \mathrm{~min}$ at $60^{\circ} \mathrm{C}$. Sanger reaction products were purified from excess of BigDye components by gel filtration through micro columns containing 600-700 $\mu \mathrm{l}$ of prepared Sephadex G-50 (GE Healthcare) with liquid removal from the dead volume by centrifugation for $2 \mathrm{~min}$ at $900 \mathrm{~g}$ and subsequently analyzed on an ABI 3130XL

\footnotetext{
Supplementary Materials 1 and 2 are available in the online version of the paper: https://vavilov.elpub.ru/jour/manager/files/SupplAgafonov_engl.pdf
}

automatic gene analyzer (ABI, USA) at the Genomics Core Facility SB RAS. DNA sequences obtained were assembled into contigs overlapping GBSS1 from exon 9 to 14, including 5 introns, by using Unipro UGENE v1.31.0 (Okonechnikov et al., 2012). Finally, at least 6 clones of GBSS1 per each of 22 Elymus accessions have been sequenced. Additionally, 42 nucleotide sequences from the NCBI GenBank were used for comparative analysis.

Multiple sequence alignment was performed using the T-Coffee program (www.tcoffee.org) and refined manually. The alignments of the GBSS1 fragment were used to generate phylogenetic trees using the maximum likelihood (ML) method on the IQ-TREE web server (Trifinopoulos et al., 2016). For each exon and intron, the best models of nucleotide substitutions were determined in PartitionFinder version 2.1.1 (Lanfear et al., 2016) with the following parameters: the AICc selection model, "greedy” search algorithm and related (linked) lengths of the branches (Lanfear et al., 2012). The previously proposed (Mason-Gamer, 2004) sequence of Bromus tectorum AY362757.1 from the NCBI GenBank was used to root the dendrograms. The statistical support of topology in IQ-TREE analysis was evaluated using 1000 replications produced by SH-aLRT (Guindon et al., 2010) and UFBoot (Minh et al., 2013) methods.

\section{Results and discussion}

The results obtained using reference accessions carriers of the genus Elymus ancestor genomes, St (genus Pseudoroegneria species) and $\mathrm{H}$ (genus Hordeum species), clearly indicated the presence of only the St and $\mathrm{H}$ genomes in all the studied species from Siberia and the Russian Far East, thus confirming that these species belong to the tetraploid $\mathrm{StH}$ genome group. Obviously, the center of species diversity for the StH genome group is shifted to the north from the center of origin of most StY genome species located in China (Lu, Salomon, 1992). Interestingly, the allotetraploid group of Elymus species of North America is also represented mainly by StH genome species (Mason-Gamer, 2001). Only rare individuals of several alien Asian StHY and StY genome species were reported there (Barkworth et al., 2007).

The most notable differences between the St and H subgenomic fragments are located in intron 13 (Fig. 1). The H subgenome sequences of this intron in all Elymus genotypes analyzed contained a 21-bp-long deletion, most likely coming from a common ancestor of the $\mathrm{H}$ and $\mathrm{P}$ subgenomes, since it is also present in modern representatives of related monogenomic species from the genera Hordeum and Agropyron. However, all St and Y subgenomes had at the very site of this deletion a relatively conservative sequence, which largely matches a sequence in the genus Pseudoroegneria, whose ancestor is believed to be the donor of the modern St genome. Small deletions are also common for other regions of this intron, but are less frequent in the other GBSS1 fragment regions analyzed.

In addition, our analysis of the accessions did not confirm the previously published data on the existence of conservative sites that are absolutely specific to the $\mathrm{H}$ and St haplomes (Shmakov et al., 2015). This was true only partially of some sequences belonging to different haplomes.

Cluster analysis of the whole GBSS1 region from 9 to 14 exon sequences, as well as separate sequences of introns or 


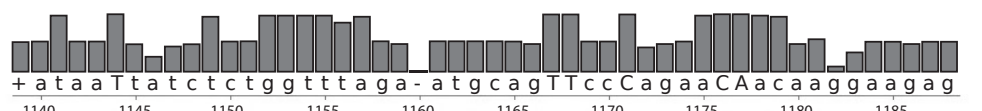

H.jub_63_H
kamKSO23_2
chaKES70_1
kroKESO3_1
len0125_4
subANA81_2
mac0135_1
jac0443_5
marGUKO9_6
komGAR01_2
komAUK03_1
marAUK50_2
marGUKO9_1
trnGAR30_1
sajZUNO2_4

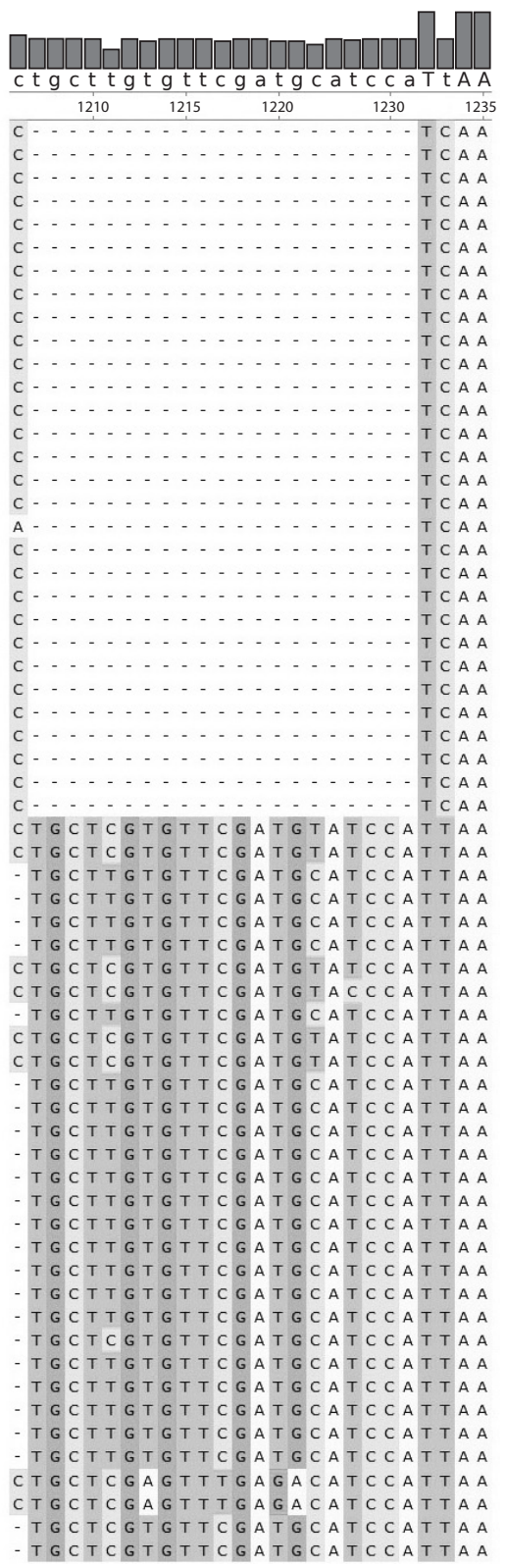

Fig. 1. $\mathrm{H}$ and St subgenome differences in intron 13 of the GBSS1 gene nucleotide sequences among Elymus species from the Asian part of Russia in comparison with the sequences of the reference species of Eurasia.

exons, showed common patterns with certain nuances of phyletic connections both within and between related groups of the Elymus taxa analyzed. The analysis of the most conservative sites (exons 9-14) showed uniformity within the same subgenomes and at the same time distinction among different subgenomes (Fig. 2).

In the species studied the two subgenomes were found clearly differentiated. For instance, the sequences of the St subgenome were divided into two groups: $\mathrm{St}_{1}$ and $\mathrm{St}_{2}$. The sequences of the $\mathrm{St}_{1}$ subgenome for Siberian species are probably older since they were found not only in the northern biotypes E. macrourus, E. jacutensis, E. kamczadalorum and more southern StY genome species E. gmelinii and E. pen- dulinus, but also in P. strigosa accession PI 499637 from the northeastern part of China.

The subgenomic group $\mathrm{St}_{2}$ was formed by a larger part of the species, including both strictly local (E. komarovii, E. uralensis, E. sajanensis, E. margaritae) and widely vicarious (E. caninus, E. sibiricus) species. This fact is clearly illustrated by nucleotide sequence peculiarities in different regions of the gene, as shown in Fig. 3. Remarkably, accession AUK-0650 of the Altai species E. margaritae contained both variants of the St subgenome. At the same time, in the set of 8 sequences for each $E$. komarovii accession GAR-0501 and E. margaritae accession GUK-1709 the sequences belonging to the St subgenome were not detected. 


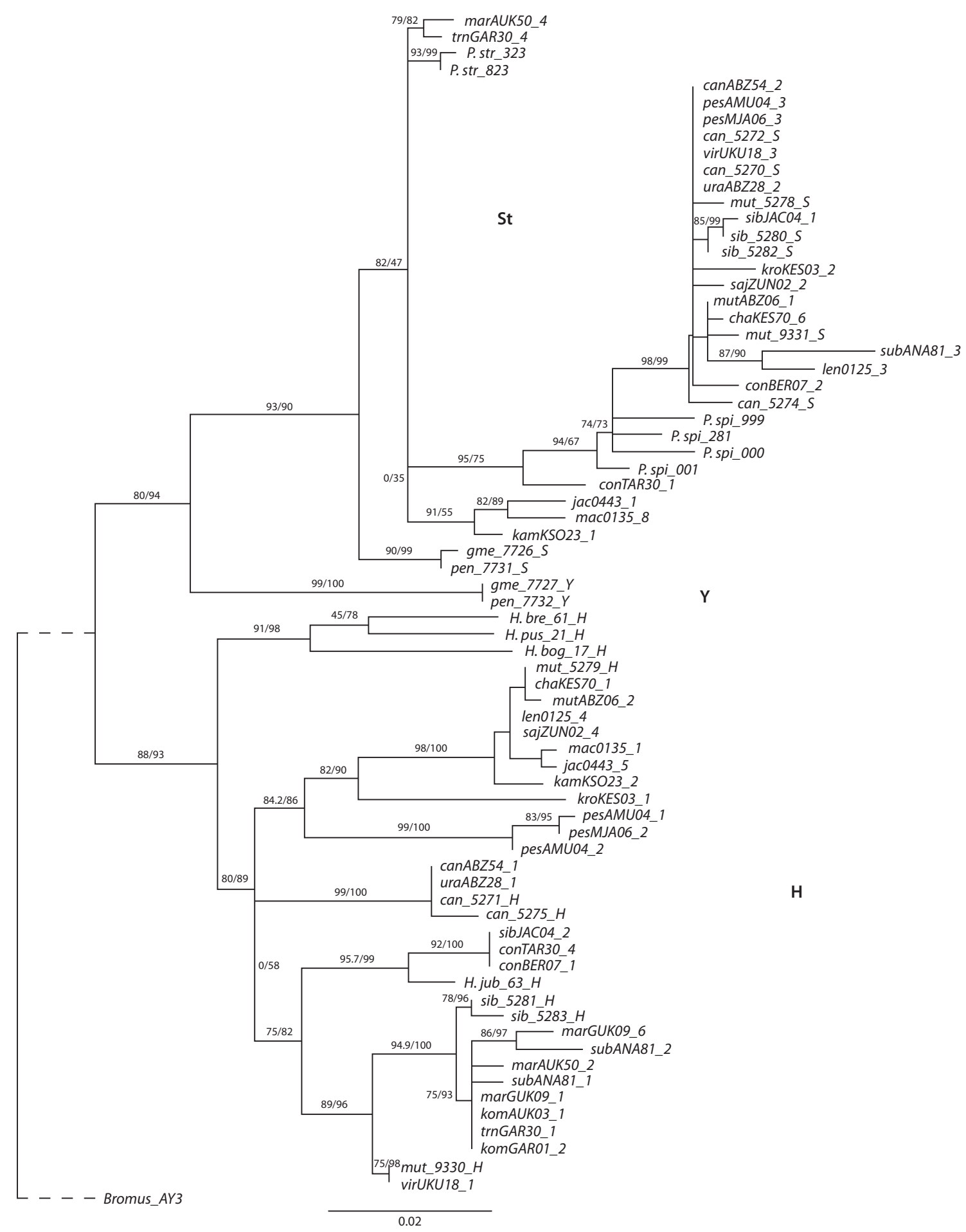

Fig. 2. The maximum likelihood tree constructed from multiple alignment of all exon (9-14) sequences of the GBSS1 gene of the St and $\mathrm{H}$ subgenomes in Elymus species from the Asian part of Russia in comparison with the sequences of the reference species of Eurasia (St, $\mathrm{H}$ and $\mathrm{Y}$ subgenomes).

SH-aLRT (\%)/UFboot (\%) support values are shown.

Sequences of a greater number of the Elymus species from North American natural accessions initially were subdivided according to the same principle (Mason-Gamer, 2001), therefore we have built a dendrogram that included the endemic species of Asian Russia in comparison with some sequences of
North American species. The sequences of the St subgenome including exons 9 to 14 with introns were used. The results are shown in Fig. 4.

In this version of the dendrogram, Asian species were also distributed among two clades with the same composition as in 

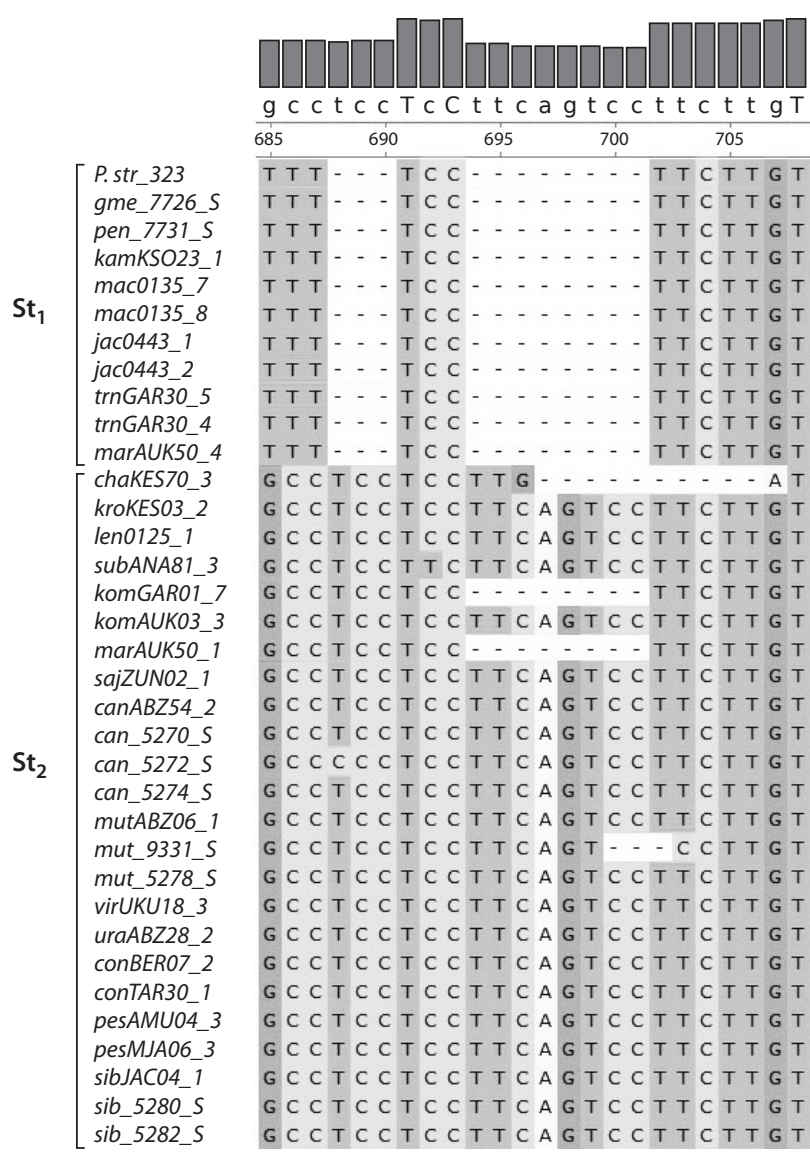

g c c t c c T c C t t c a g t c c t t c t t g T

T T T - . - T C C - - T T T T T G T

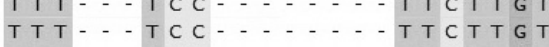

TTT - . T C C . . . . T T T C T T T G T

TT T - - T T C - . - . T T T C T T G T

TTT - . T C C - . - . T T T C T T G T

TT T - . T C C - . . . T T T T T T G T

TT T - . T T C . . . . T T T C T T T G

T T T - . TCC - . - . . T T T C T T G T

TTT - - T C C - - - . T T T T T T G T

TTT - . TCC . . . . T T T C T T G T

TT T - . T T C . . . . T T C T T G T

G C C T C C T C C T T G

GCCTCCTCCT TCAGTCCTTCTTGT

G C C T C C T C C T T CA A T C CTTCTTGT

G C C T C C T T C T T CA G T C C T T C T T G T

G C C T C C T C C

T T C T T G T

GCCTCCTCCTTCAGTCCTTCTTGT

G C C T C C T C C - . - . . T T C T T G T

G C C T C C T C C T T C A G T C C T T C T T G T

G C C T C C T C C T T C A G T C C T T C T T G T

GCCTCCTCCTTCAGTCCTTCTTGT

G C C C C C T C C T T CA G T C C T T C T T G T

G C C T C C T C C T T CA A T C CTTCTTGT

G C C T C C T C C T T CA G T C C T T C T T G T

G C C T C C T C C T T C AGT - - C C T T G T

G C C T C C T C C T T C A G T C C T T C T T G T

GCCTCCTCCTTCA GTCCTTCTTGT

GCCTCCTCCTTCAGTCCTTCTTGT

G C C T C C T C C T T C A G T C C T T C T T G T

G C C T C C T C C T T CA G T C CTTCTTGT

GCCTCCTCCTTCAGTCCTTCTTGT

G C C T C C T C C T T C A G T C C T T C T T G T

G C C T C C T C C T T CA G T C C T T C T T G T

G C C T C C T C C T T CA G T C C T T C T T G T

G C C T C C T C C T T C A G T C C T T C T T G T

\begin{tabular}{|c|c|c|c|c|c|c|c|}
\hline \multicolumn{4}{|c|}{ C CTCTTgta } & C G & $\mathrm{t} T \mathrm{CC}$ & $\mathrm{TGG}$ & $\mathrm{tGGg}$ \\
\hline & 380 & & 885 & 990 & & 1250 & 128 \\
\hline$-\mathrm{C} T$ & $\mathrm{C} T$ & T C & A A & G G & $\mathrm{C} T \mathrm{~T} \mathrm{C}$ & T G G & C G G G \\
\hline$-\mathrm{C} T$ & $\mathrm{C} T$ & & A A & G G & $C T T C$ & T G G & C G G T \\
\hline$-\mathrm{C} T$ & $\mathrm{C} T$ & & A A & G G & $\mathrm{C} T \mathrm{~T} \mathrm{C}$ & $T$ G G & C G G T \\
\hline$-\mathrm{C} T$ & $\mathrm{C} T$ & & A A & G G & C T T C & T G G & C G G G \\
\hline$-\mathrm{C} T$ & $\mathrm{C} T \mathrm{~T}$ & & A A & G G & $\mathrm{C} T \mathrm{~T} \mathrm{C}$ & T G G & C G G G \\
\hline$-\mathrm{C} T$ & $\mathrm{C} T$ & & A A & G G & $\mathrm{C} T \mathrm{~T} \mathrm{C}$ & T G G & G G G G \\
\hline$-C T$ & C T & T C & A A & G G & $C T T C$ & $T G G$ & $A G G G$ \\
\hline$-\mathrm{C} T$ & $\mathrm{C} T$ & & A A & G G & $\mathrm{C} T \mathrm{~T} \mathrm{C}$ & T G G & A G G G \\
\hline$-\mathrm{C} T$ & $\mathrm{C} T$ & T C & A A & G G & $\mathrm{C} T \mathrm{~T} \mathrm{C}$ & T G G & C G G G \\
\hline$-\mathrm{C} T$ & $\mathrm{C} T$ & T C & A A & G G & $\mathrm{C} T \mathrm{~T} \mathrm{C}$ & T G G & C G G G \\
\hline$-\mathrm{C} T$ & $\mathrm{C} T$ & T C & A A & G G & $\mathrm{C} T \mathrm{~T} \mathrm{C}$ & T G G & C G G G \\
\hline C C T & $\mathrm{C} T$ & T G & T A & C G & $T T C C$ & T G G & $T$ G G G \\
\hline C C T & $\mathrm{C} T$ & T G & T A & C G & T T C C & T G G & T G G G \\
\hline C C T & $\mathrm{C} T$ & & T A & C G & $T T C C$ & T G G & T G G G \\
\hline C C T & $\mathrm{C} T$ & & T A & C G & $T T C C$ & T G G & $T$ G G G \\
\hline C C T & $\mathrm{C} T$ & T G & T G & G G & C T T C & T G G & C G G G \\
\hline C C T & $\mathrm{C} T$ & T G & T A & C G & G T C C & T G G & G G G G \\
\hline C C T & $\mathrm{C} T$ & T G & T G & C G & $C T T C$ & T G G & C G G G \\
\hline C C T & $\mathrm{C} T$ & T G & T A & C G & $T T C C$ & T G G & $T$ G G G \\
\hline C C T & $\mathrm{C} T$ & T G & T A & C G & $T T C C$ & T G G & T G G G \\
\hline C C T & $\mathrm{C} T$ & $\mathrm{~T} \mathrm{G}$ & $\mathrm{T} A$ & C G & T T C C & $T G G$ & T G G G \\
\hline $\mathrm{CC} T$ & C T & T G & T A & C G & $T T C C$ & T G G & $T$ G G G \\
\hline $\mathrm{C} C \mathrm{~T}$ & $\mathrm{C} T$ & T G & T A & C G & $T T C C$ & T G G & $T$ G G G \\
\hline C C T & $\mathrm{C} T$ & T G & $\mathrm{T} A$ & C G & $T T C C$ & $T$ G G & $T$ G G G \\
\hline C C T & $\mathrm{C} T$ & & T A & C G & T T C C & T G G & T G G G \\
\hline C C T & $\mathrm{C} T$ & & T A & C G & T T C C & T G G & T G G G \\
\hline C C T & $\mathrm{C} T$ & & $\mathrm{~T} A$ & C G & $T T C C$ & $T$ G G & T G G G \\
\hline $\mathrm{C} C \mathrm{~T}$ & $\mathrm{C} T$ & T G & T A & $\mathrm{C} \mathrm{G}$ & $T T C C$ & $T$ G G & $T$ G G G \\
\hline C C T & C T & T G & T A & C G & $T T C C$ & T G G & G G G G \\
\hline C C T & $\mathrm{C} T$ & T G & $\mathrm{T} A$ & C G & $T T C C$ & T G G & T G G G \\
\hline C C T & $\mathrm{C} T$ & & T A & C G & $T T C C$ & T G G & $T$ G G G \\
\hline C C T & $\mathrm{C} T$ & & $\mathrm{~T} A$ & C G & $T T C C$ & $T$ G G & T G G G \\
\hline C C T & $\mathrm{C} T$ & & & C G & $\mathrm{T} T \mathrm{TCC}$ & T G G & $T$ G G G \\
\hline C C T & $\mathrm{C} T$ & & & C G & $T T C C$ & T G G & T G G G \\
\hline C C T & $\mathrm{C} T$ & & & $\mathrm{C} \mathrm{G}$ & $T T C C$ & T G G & $T$ G G G \\
\hline
\end{tabular}

Fig. 3. Differentiation of St subgenomes on the basis of differences in nucleotide sequences in different parts of the GBSS1 gene in Elymus species from the Asian part of Russia in comparison with sequences in reference accessions of the Eurasian species.

the dendrogram constructed using exons alone. Some of the North American species (marked by dots on the dendrogram) together with the Asian species $P$. strigosa formed a joint clade with the group of the $\mathrm{St}_{1}$ subgenome, while the others met in the $\mathrm{St}_{2}$ group along with all accessions of the North American species $P$. spicata. GBSS1 sequences of the Y subgenome in E. gmelinii and E. pendulinus showed a closer relationship with the $\mathrm{St}_{2}$ group, which does not contradict the data on the evolutionary origin of this subgenome (Mason-Gamer et al., 2010a).

The H subgenome showed a similar pattern of differentiation. Figure 5 shows a dendrogram constructed from complete sequences of the $\mathrm{H}$ genome introns and exons from Russian and North American species (the latter are marked with dots in the figure). Two perennial Hordeum species (marked with asterisks) were taken as references. Gene copies from the $\mathrm{H}$ genome appeared to be divided into two main clades (designated as $\mathrm{H}_{1}$ and $\mathrm{H}_{2}$ ). Clade $\mathrm{H}_{1}$ included exclusively Russian species, while clade $\mathrm{H}_{2}$ was formed by Russian northeastern and all North American species. Each of these clades has its own ancestral taxon from the contemporary genus Hordeum: widespread in Eurasia $H$. jubatum for the Russian $\mathrm{H}_{1}$ group and North American H. californicum Covas \& Stebbins for the $\mathrm{H}_{2}$ group.
Russian species from clade $\mathrm{H}_{1}$ showed significantly greater differentiation than the species from heterogeneous clade $\mathrm{H}_{2}$. Clade $\mathrm{H}_{1}$ appeared to be divided into 3 subclades. Primarily three clones of the northeastern species E. kronokensis and E. peschkovae went to a separate group. This fact indirectly confirms the significant isolation of the latter from Siberian E. confuses, although they are similar in spike morphology. E. confusus, in turn, clustered most closely with the reference $H$. jubatum. The most distant cluster was formed by all accessions of E. caninus with an addition of the clone of South Ural endemic E. uralensis. The largest cluster was formed by the Siberian mountain species E. komarovii, E. transbaicalensis and $E$. margaritae, which an addition of a pair of reference clones of E. sibiricus and, as the most unexpected fact, a clone of E. subfibrosus accession from Chukotka. Remarkably, the different reference accessions of $E$. mutabilis fell into different H subgenome clades.

Mixed clade $\mathrm{H}_{2}$ included not only all North American clones of Elymus species together with $H$. californicum, but also clones from different regions of Russia: E. kamczadalorum and E. charkeviczii (species from the Kamchatka Peninsula), E. macrourus, E. jacutensis, E. lenensis (northern accessions from the Taymyr Peninsula), E. sajanensis (a Siberian mountain species) and two of three E. mutabilis (reference Chinese 


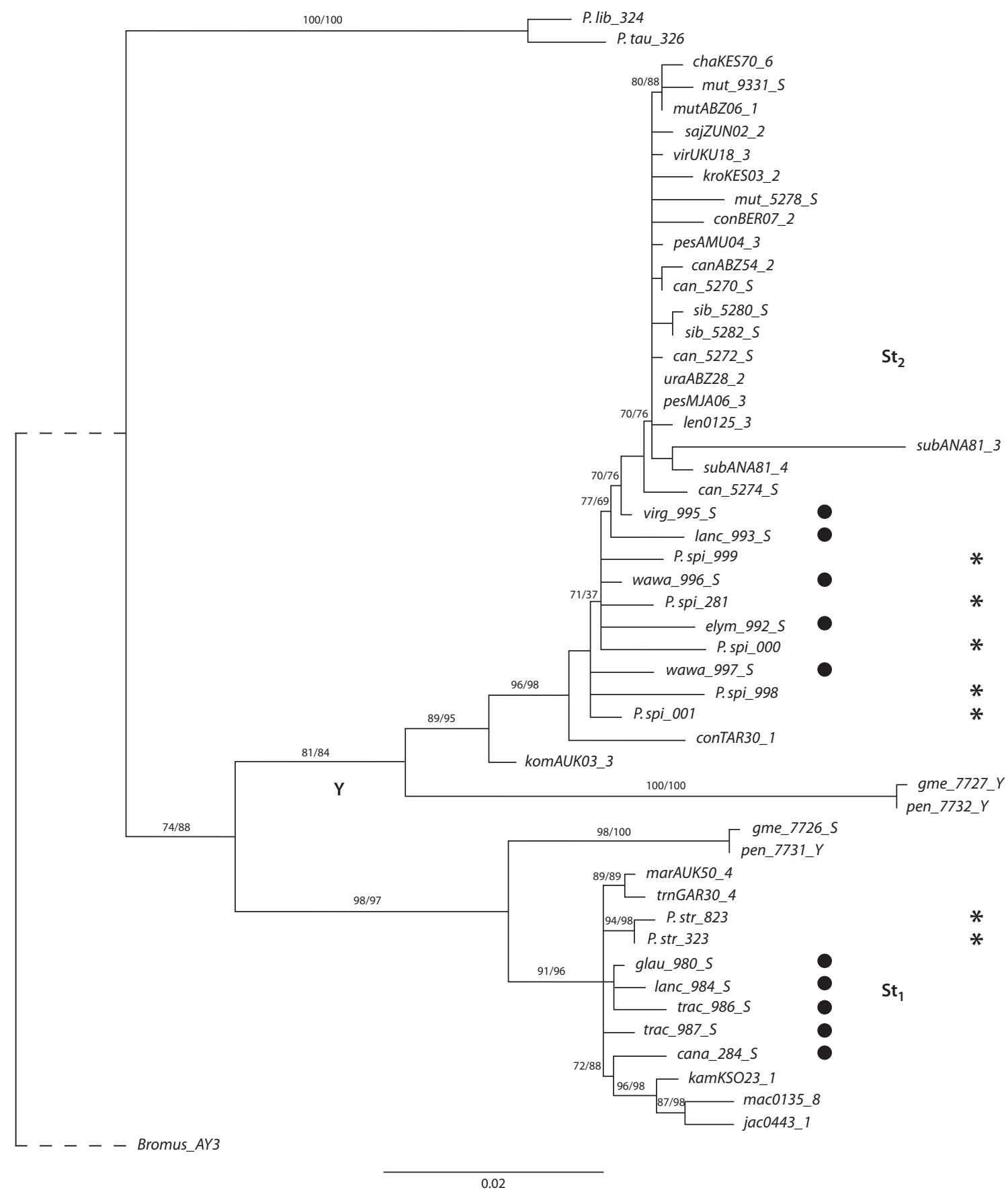

Fig. 4. The maximum likelihood tree constructed from multiple alignment of St subgenome GBSS1 intron and exon (9-14) sequences in Elymus species from the Asian part of Russia in comparison with sequences in Eurasian and North American (marked by dots) reference species (St and Y subgenomes). Asterisks indicate Pseudoroegneria species carriers of the St genome.

SH-aLRT (\%)/UFboot (\%) support values are shown.

mut_5279_H and South Ural ABZ06_2). The third reference, mut_9330_H E. mutabilis, from Altai fell into clade $\mathrm{H}_{1}$. Thereby, only some tendency toward relations between the North American accessions and northern or eastern accessions of Russian species can be derived from the $\mathrm{H}$ subgenome sequence analysis. The close relationship between American and Kamchatka species is easier to understand, taken into ac- count the historical connections of these flora with each other, as well as with the species from the wide northern distribution areas of E. macrourus and E. jacutensis. It is more difficult to explain the close proximity of Chinese and South Ural accessions of E. mutabilis to this group.

Nevertheless, GBSS1 gene variability provides a tool to trace evolutionary relations of species and local geographical 


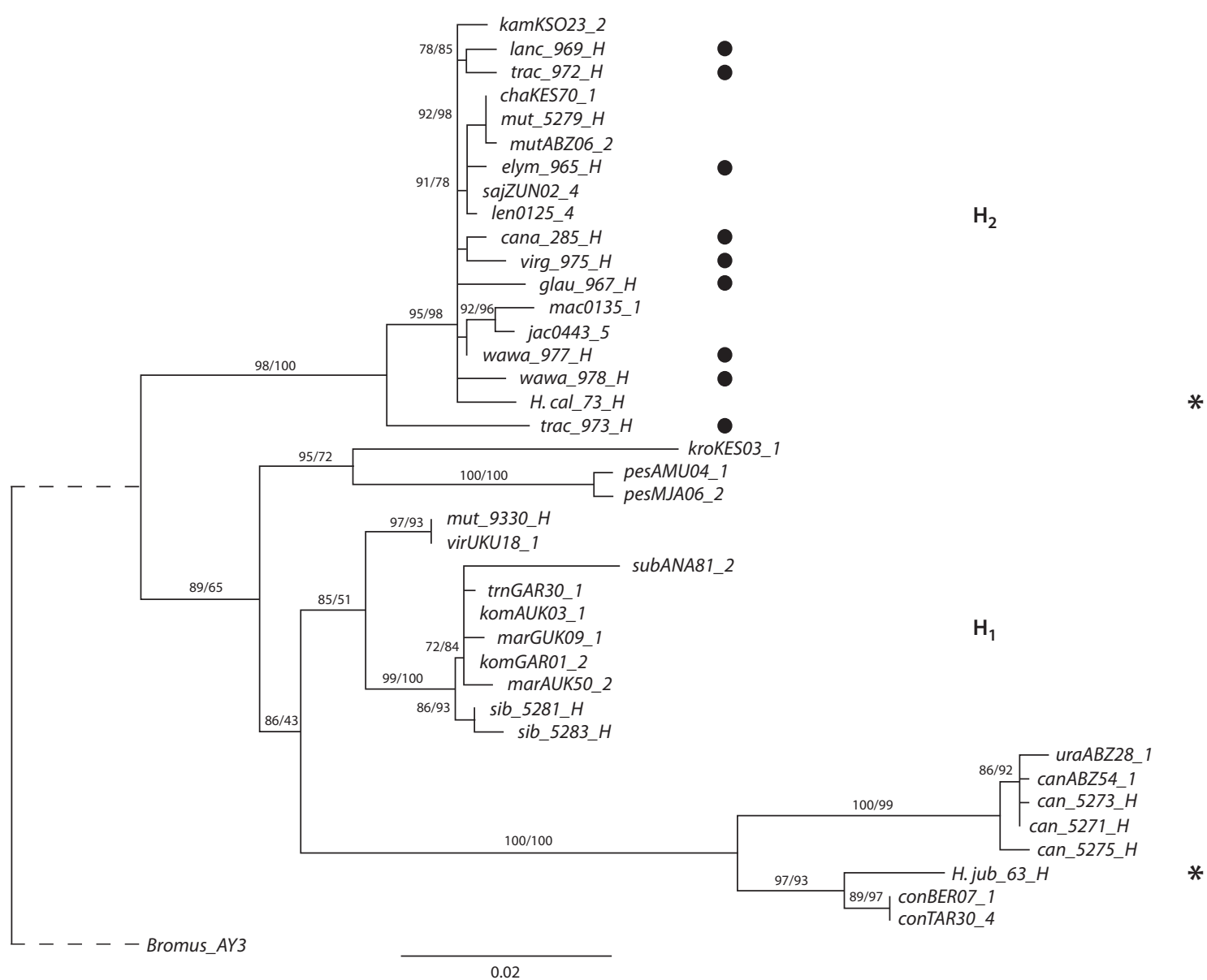

Fig. 5. The maximum likelihood tree constructed from multiple alignment of $\mathrm{H}$ subgenome GBSS1 gene intron and exon (9-14) sequences in Elymus species from the Asian part of Russia in comparison with sequences in Eurasian and North American (marked by dots) reference species. Asterisks indicate the carriers of the $\mathrm{H}$ genome: the North American species Hordeum californicum and the widely distributed species of Asian origin H. jubatum.

SH-aLRT (\%)/UFboot (\%) support values are shown.

races from Siberia and the Russian Far East. If we consider the relative position of the accessions inside the clades of the subgenomes, we will see that the clusters combined the species accessions according to their perceived relationship. E. jacutensis and E. macrourus species, for instance, united into the common clusters in both $\mathrm{H}$ and St clades (see Fig. 2), as well as on separate dendrograms of these subgenomes (see Fig. 4, 5), thereby confirming the earlier assumptions about E. jacutensis being an aristate subspecies of $E$. macrourus (Tsvelyov, 1964). This fact is consistent with data on comparative morphological and peptide electrophoretic analyses and hybridization of these species’ particular biotypes (Agafonov, 2008).

A comparative sequence analysis confirmed the isolation of E. kamczadalorum from the Kamchatka species E. charkeviczii, which was previously established using data on comparative morphology, electrophoresis of seed endosperm storage proteins, sexual hybridization (Agafonov, Gerus, 2008) and molecular ISSR analysis (Kobozeva et al., 2017). The species E. komarovii and E. transbaicalensis formed indistinguishable branches inside clade $\mathrm{H}_{1}$ together with the Altai species E. margaritae, while E. transbaicalensis and E. margaritae clones were grouped inside clade $\mathrm{St}_{1}$. The phylogenetic proximity of the first two species has been repeatedly experimentally confirmed previously (Agafonov et al., 2019), while the degree of E. margaritae isolation is currently being studied using biosystematic methods. The most unexpected data were obtained regarding the relationships in the group of South Ural biotypes of E. uralensis, E. viridiglumis, E. caninus, and E. mutabilis. These data are currently being verified in the field and laboratory experiments.

\section{Conclusion}

Therefore, despite a complicated reticulate evolution in parallel with various related allopolyploid genera and constantly ongoing active microevolutionary transformations, basic genomes seem to have retained unique ancestral features. This makes it relatively easy to identify the genomic composition and to classify modern species within the framework of a phylogenetically oriented taxonomic model of the genus. In our opinion, the integrity of the genus ought to be preserved, because some species in the independent genus Roegneria with the genomic formula StY (Baum et al., 1991) are similar 
in morphology to species in the newly proposed genus Campeiostachys with the genomic formula StHY (Baum et al., 2011), the species of which are significantly different from each other in morphology. The St genome originating from the ancestors of the genus Pseudoroegneria seems to be an anchoring constant for a genetic unification of all members of the genus.

We suppose that differentiation of the genus should be based on a model of microevolutionary complexes representing an aggregate of taxa evolving through hybridization and introgression. The degree of taxa relationship within the complex should be confirmed using biosystematic methods with the obligatory determination of the ability to cross, i. e. taking into account the position in the system of recombination (RGP) and inrogressive (IHP) gene pools (Agafonov, Salomon, 2002). In fact, the microevolutionary complex is a projection of the RGP collection onto the taxonomic model of the genus, considering the genomic constitution of the species. Each microevolutionary complex should be thought of as a branched system of different ranks of taxa (species and subspecies), remaining therefore a phylogenetically confirmed structure.

In the future, it is necessary to determine the taxonomic rank of microevolutionary complexes, which can be sections or aggregates of the same species in a broad sense, as shown by the example of a revision of Pendulini (Nevski) Tzvelev sub-section of the Goulardia (Husn.) Tzvelev section (Kobozeva, Agafonov, 2015).

\section{References}

Agafonov A.V. Biosystematic research of the complex Elymus macrourus $-E$. jacutensis and the critical taxon E. ircutensis (Triticeae: Poaceae). Rastitel'nyj Mir Aziatskoj Rossii = Plant Life of Asian Russia. 2008;2:20-32. (in Russian)

Agafonov A.V., Gerus D.E. Study of the polymorphic complex Elymus charkeviczii Probat. s. l. (Triticeae: Poaceae) in the Kamchatka Peninsula from the viewpoint of biosystematics and taxonomical genetics. Rastitel'nyj Mir Aziatskoj Rossii = Plant Life of Asian Russia. 2008;2:58-70. (in Russian)

Agafonov A.V., Nikonova (Gerus) D.E., Shabanova (Kobozeva) E.V. The variability and specificity of the histone $\mathrm{H} 1$ among the Siberian species Elymus transbaicalensis, E. komarovii, E. sajanensis, E. kronokensis (Poaceae) and some morphologically deviating forms. Turczaninowia. 2019;22(1):5-18. DOI 10.14258/ turczaninowia.22.1.1. (in Russian)

Agafonov A.V., Salomon B. Genepools among SH genome Elymus species in boreal Eurasia. In: Hernández P. et al. (Eds.) Triticeae IV. Consejeria de Agricultura y Pesca. Spain, Sevilla, 2002;37-41.

Barkworth M.E., Cambell J.J.N., Salomon B. Elymus L. In: Barkworth M.E. et al. (Eds.). Flora of North America. New York; Oxford: Oxford Univ. Press, 2007;24:288-343.

Baum B.R., Yang J.-L., Yen C., Agafonov A.V. A taxonomic revision of the genus Campeiostachys Drobov. J. Syst. Evol. 2011;49(2):146159.

Baum B.R., Yen C., Yang J.-L. Roegneria: its generic limits and justification for its recognition. Can. J. Bot. 1991;69:282-294.

Dewey D.R. The genomic system of classification as a guide to intergeneric hybridization with the perennial Triticeae. In: Gustafson J.P. (Ed.). Gene Manipulation in Plant Improvement. New York, USA: Plenum Publ. Corp., 1984;209-279.

Guindon S.E.P., Dufayard J.C.C.O., Lefort V., Anisimova M., Hordijk W., Gascuel O. New algorithms and methods to estimate maximum-likelihood phylogenies: assessing the performance of
PhyML 3.0. Syst. Biol. 2010;59:307-321. DOI 10.1093/sysbio/ syq010.

Helfgott D.M., Mason-Gamer R.J. The evolution of North American Elymus (Triticeae, Poaceae) allotetraploids: evidence from phosphoenolpyruvate carboxylase gene sequences. Syst. Bot. 2004;29: 850-861.

Khanuja S.P., Shasany A.K., Darokar M., Kumar S. Rapid isolation of DNA from dry and fresh samples of plants producing large amounts of secondary metabolites and essential oils. Plant Mol. Biol. Rep. 1999;17:74. DOI 10.1023/A:1007528101452.

Kobozeva E.V., Agafonov A.V. Revision of the subsection Pendulini (Nevski) Tzvelev of the genus Elymus L. (Poaceae). Sistematicheskie Zametki po Materialam Gerbariya imeni P.N. Krylova TGU $=$ Systematic Notes on the Materials of P.N. Krylov Herbarium of the Tomsk State University. 2015;112:22-31. DOI 10.17223/ 20764103.112.3. (in Russian)

Kobozeva E.V., Emceva M.V., Asbaganov S.V., Agafonov A.V. Taxonomical specificity among species from the Russian Far East Elymus kamczadalorum, E. charkeviczii s. l. and E. kronokensis revealed by ISSR-markers. Rastitel'nyj Mir Aziatskoj Rossii = Plant Life of Asian Russia. 2017;3(27):43-50. DOI 10.21782/RMAR1995-24492017-3(43-50). (in Russian)

Lanfear R., Calcott B., Ho S.Y.W., Guindon S. PartitionFinder: combined selection of partitioning schemes and substitution models for phylogenetic analyses. Mol. Biol. Evol. 2012;29:1695-1701.

Lanfear R., Frandsen P.B., Wright A.M., Senfeld T., Calcott B. PartitionFinder 2: new methods for selecting partitioned models of evolution for molecular and morphological phylogenetic analyses. Mol. Biol. Evol. 2016;34(3):772-773. DOI 10.1093/molbev/ msw260.

Löve A. Conspectus of the Triticeae. Feddes Repert. 1984;95:425-521.

Lu B.-R. The genus Elymus in Asia. Taxonomy and biosystematics with special reference to genomic relationships. In: Wang R.R.-C., Jensen K. (Eds.). Proc. 2nd Int. Triticeae Symp. Logan, Utah, USA, 1994;219-233.

Lu B.-R., Salomon B. Differentiation of the SY genomes in Asiatic Elymus. Hereditas. 1992;116:121-126.

Mason-Gamer R.J. Origin of North American Elymus (Poaceae: Triticeae) allotetraploids based on granule-bound starch synthase gene sequences. Syst. Bot. 2001;26:757-768.

Mason-Gamer R.J. Reticulate evolution, introgression, and intertribal gene capture in an allohexaploid grass. Syst. Biol. 2004;53:25-37.

Mason-Gamer R.J. Allohexaploidy, introgression, and the complex phylogenetic history on Elymus repens (Poaceae). Mol. Phyl. Evol. 2008;47:598-611.

Mason-Gamer R.J. Phylogeny of a genomically diverse group of Elymus (Poaceae) allopolyploids reveals multiple levels of reticulation. PLoS One. 2013;8:e78449. DOI 10.1371/journal. pone. 0078449

Mason-Gamer R.J., Burns M.M., Naum M. Phylogenetic relationships and reticulation among Asian Elymus (Poaceae) allotetraploids: analysis of three nuclear genes. Mol. Phyl. Evol. 2010a;54:10-22. DOI 10.1016/j.ympev.2009.10.002.

Mason-Gamer R.J., Burns M.M., Naum M. Reticulate evolutionary history of a complex group of grasses: phylogeny of Elymus StStHH allotetraploids based on three nuclear genes. PLoS One. 2010b;5(6): e10989. DOI 10.1371/journal.pone.0010989.

Mason-Gamer R.J., Weil C.F., Kellogg E.A. Granule-bound starch synthase: structure, function, and phylogenetic utility. Mol. Biol. Evol. 1998;15:1658-1673.

Minh B.Q., Nguyen M.A.T., von Haeseler A. Ultrafast approximation for phylogenetic bootstrap. Mol. Biol. Evol. 2013;30:1188-1195.

Okonechnikov K., Golosova O., Fursov M. Ugene team. Unipro UGENE: a unified bioinformatics toolkit. Bioinformatics. 2012;28: 1166-1167.

Shmakov N.A., Afonnikov D.A., Belavin P.A., Agafonov A.V. The suitability of the BMY2 and WAXY genes and internal transcribed 
spacers of RRNA as markers for studying genetic variability in Elymus species. Russ. J. Genet.: Appl. Res. 2015;5(3):300-307. DOI 10.1134/S207905971503017X

Trifinopoulos J., Nguyen L.-T., von Haeseler A., Minh B.Q. W-IQTREE: a fast online phylogenetic tool for maximum likelihood analysis. Nucleic Acids Res. 2016;W1:W232-W235. DOI 10.1093/ nar/gkw256.

Tsvelyov N.N. Wheatgrass Roegneria C. Koch. In: Arctic Flora of the USSR. Moscow; Leningrad, 1964;2:230-247. (in Russian)
Tsvelyov N.N., Probatova N.S. The genera Elymus L., Elytrigia Desv., Agropyron Gaertn., Psathyrostachys Nevski and Leymus Hochst. (Poaceae: Triticeae) in the flora of Russia. In: V.L. Komarov Memorial Lectures. Vladivostok: Dalnauka Publ., 2010;57:5-102. (in Russian)

Wagner A., Blackstone N., Cartwright P., Dick M., Misof B., Snow P., Wagner G.P., Bartels J., Murtha M., Pendleton J. Surveys of gene families using polymerase chain-reaction - PCR selection and PCR drift. Syst. Biol. 1994;43(2):250-261.

ORCID ID

A.V. Agafonov orcid.org/0000-0002-1403-5867

S.V. Asbaganov orcid.org/0000-0002-7482-7495

I.V. Morozov orcid.org/0000-0002-0307-4203

A.A. Bondar orcid.org/0000-0001-9181-0487

Acknowledgements. This work was carried out as part of the state grant for the Central Siberian Botanical Garden SB RAS "Estimation of the morphogenetic potential of the North Asian plant population by experimental methods" (state registration number: AAAA-A17-117012610051-5) with partial support from the Russian Fund for Basic Research (project No. 18-04-01030). The materials of the bio-resource scientific collection of the CSBG SB RAS "Collections of living plants in open and closed ground" USU No. 440534 were used. DNA sequencing was performed at SB RAS Genomics Core Facility (ICBFM, Novosibirsk). The authors would like to acknowledge engineer M.V. Yemtseva (CSBG SB RAS) for important assistance in the GBSS1 gene sequencing result analysis.

Conflict of interest. The authors declare no conflict of interest.

Received June 6, 2019. Revised July 30, 2019. Accepted July 31, 2019. 